\title{
IDENTIFICATION OF BIOACTIVE COMPOUNDS FROM EGYPTIAN MULBERRY FRUITS AND THEIR USES IN IMPROVEMENT THE QUALITY OF SOME FOODS
}

\author{
Owon *, M. A.; A. M. Gafar**, S. M. Saleh*; and Marwa, M. \\ Shaheen ** \\ * Food Technology Dept. Fac. Of Agric. Kafrelsheikh Univ. Egypt \\ ${ }^{* *}$ Food Technology Research Inst., Agric. Res. Center, Giza, \\ Egypt
}

\begin{abstract}
This work was carried out to study the chemical and nutritional properties of some egyptian mulberry species. White, black mulberry, goldenberry and strawberry fruits were analyzed for their proximate chemical composition, phenolic compounds, flavonoids contents, vitamins, some reducing and non reducing sugars, beta-carotenoids and anthocyanin to evaluate their importance in human nutrition. The results showed that white mulberry contained $79.34 \%$ moisture, $12.98 \%$ protein, $9.03 \%$ ether extract, $6.36 \%$ ash, $8.32 \%$ crude fiber and $63.31 \%$ carbohydrates, while, the black mulberry contained $76.45 \%$ moisture, $10.85 \%$ protein, $7.21 \%$ ether extract, $4.79 \%$ ash, $5.45 \%$ crude fiber and $71.7 \%$ carbohydrates. On the other hand, goldenberry contained $77.78 \%$ moisture, $9.16 \%$ protein, $9.95 \%$ ether extract, $5.44 \%$ ash, $16.32 \%$ crude fiber and $59.13 \%$ carbohydrates. It could be noticed that strawberry recorded $90.87 \%$ moisture, $7.65 \%$ protein, $3.74 \%$ ether extract, $3.48 \%$ ash, $10.32 \%$ crude fiber and $74.81 \%$ carbohydrates. High concentrations of phenolic compounds and flavonoids from this egyptian mulberry species were found. It can be concluded that the consumption of white, black mulberry, goldenberry and strawberry in different combinations could provide a reasonable daily recommended amount of essential nutrients for maintenance of healthy life and normal body functioning. The organoleptic evaluation of juices and jams prepared by mixing strawberry with white, black mulberry and goldenberry at three ratios 25,50 and $75 \%$ was carried out.
\end{abstract}

\section{INTRODUCTION}

Mulberry (Morus $s p$ ) has been domesticated over thousands of years and has been adapted to a wide area of tropical, subtropical, and temperate zones of Asia, Europe, North and South America, and Africa. The most important widely grown anthocyanin-rich Morus species are Morus alba, Morus rubra, and Morus nigra. Morus alba has white and purple fruits with avery sweet taste and low acidity. Its fruits are perishable and mostly used for fresh consumption. M. rubra, known as " red mulberry", is high in dry matter, sweet taste and low acidity. M. nigra, known as "black mulberry", has juicy fruits with 
extraodinary color and a unique, slightly acidic flavor. Recently, red and black mulberries have gained an important position in the food industry due to the presence of anthocyanins. Several researchers have previously reported that anthocyanins have remarkable as antioxidants and free- radical scavenging activities (Stintzing et al. 2002). Additionally, multiple findings suggest that anthocyanin content of berries and red fruits may provide possible health benefits such as reduced risk of coronary heart diseases, stroke, certain types of cancers and aging (Prior, 2003; Zafra-Stone et al. 2007).

Identification and quantification of anthocyanins, phenolics and antioxidative properties of red fruits, especially berries, are well defind (Celik et al. 2008). Also, there are number of detailed studies showing health benefits of the individual fruits. However, studies on characterization and quantification of phtochemical and antioxidative properties of mulberry fruits are very limited (Ercisli and Orhan, 2007).

Lee et al. (2004) found that mulberries have cyanidin-based anthocyanins, particularly cyanidin-3-glucoside and cyanidin-3rutinoside. However, the biological and pharmacological effects of these fruits are still poorly defined. In recent studies, Naderi et al. (2004) found that extracts of $M$. nigra fruits have protective action against peroxidative damage to biomembranes and biomolecules.

Mulberry fruit was welcome in the market, because it can provide plentiful phenolic compounds and nuturally occurring a-glucosidase inhibitors, which may be protective against certain human disease, such as cancer or chronic diseases (Du et al. 2008; Perez-Gregorio et al. 2011).

Strawberries are popular fruits grown in Egypt and many other countries. It could be consumed fresh or in many other forms (juice, concentrate jam, jelly and dried re-hydrated with yogurt and bakery products). In Egypt,10.5 thousand feddans were cultivated with strawberries in 2013/2014 and produced about 283471 tons (Bulletin of The Agricultural Statistics, 2015). Part of the local yield is preserved in a frozen form for making different products out of the season.

Wang and Jiao (2000) showed that strawberry juice exhibited a high level of antioxidant capacity against free radical species including superoxide radicals, hydrogen peroxide, hydroxyl radicals, and singlet oxygen. The polyphenolic composition and antioxidant properties of different strawberry cultivars have been the subject of many investigations. Several strawberry cultivars have been found to display significantly higher levels of antioxidant activity than others (Meyers et al. 2003; Wang et al. 2002), and the individual flavonoid and phenolic 
acid compounds have been found to differ among cultivars (Häkkinen and Törrönen, 2000).

Goldenberries or cape gooseberries (Physalis peruviana Linn., Solanaceae) are short-lived perennials. The fruit with an approximate weight of $4-5 \mathrm{~g}$ is covered by a brilliant yellow peel (Mayorga et al. 2001). It is somewhat tomato-like in flavor and appearance, although the taste (sweet and sour) is much richer with a hint of tropical luxuriance. Goldenber-ries have been grown in Egypt, South Africa, India, NewZealand, Australia and Great Britain (Morton, 1987; McCain, 1993; Ramadan and Moersel, 2004).

International markets exist for many exotic fruits, and recently, the processing of tropical fruits started in many countries (Ramadan and Moersel, 2007). In 2005, there were more than 1.8 million acres of berry crops worldwide, including 966 acres of gooseberries. The single plant may yield 300 fruits and carefully tended plants can provide 20-33 tons/ha. Fruits are long-lasting, can be stored for several months when well frozen. The fruit has been used as a good source of provitamin A, minerals, vitamin C and B-complex. Goldenberry juice yield is about $70 \%$ of the berry weight (Ramadan and Moersel, 2007). Sugar content in the juice is $4.9 \mathrm{~g} / 100 \mathrm{~g}$ and the main compounds are sucrose and fructose. Ascorbic acid level in goldenberry $(46 \mathrm{mg} / 100 \mathrm{~g})$ turns out to be higher than in most fruits such as pear peach $(7 \mathrm{mg} / 100 \mathrm{~g})$, and somewhat comparable with orange $(50 \mathrm{mg} / 100 \mathrm{~g})$. In goldenberry, quercetin was the main phenolic compounds, followed by myricetin and kaempferol (Häkkinen et al. 1999). Goldenberry juice is rich in water and fat-soluble bioactive compounds and could be a novel source of functional drinks (Ramadan, 2011).

\subsection{Materials}

\section{MATERIALS AND METHODS}

\subsubsection{White mulberry, black mulberry, golden berry and strawberry} fruits:

Fruits were obtained from the local performer market of Kafr ElSheikh city, Egypt. Fruits collected in March 2014. They were cleaned ,separated from foreign matters, blended to pass through 100 mesh screen sieve, then kept in polyethylene bags and stored in freezer at ($18 \pm 2^{\circ} \mathrm{C}$ ) until analysis and other uses.

\subsubsection{Solvents:}

All chemical and solvents used in this investigation were obtained from El- Gomhoriya Company for chemical and drugs, Tanta city, Egypt. 


\subsection{Methods}

\subsubsection{Chemical analysis:-}

Moisture, crude protein, ether extract, ash and crude fiber were determined according to the methods of A.O.A.C. (2010). All the above mentioned determinations were expressed as $\mathrm{g} / 100 \mathrm{~g}$ sample and performed in triplicate. Total carbohydrates were estimated by difference. $\%$ carbohydrates $=100$ - $(\%$ crude protein $+\%$ crude fat+ $\%$ ash $+\%$ crude fibers).

2.2.2. Identification and quantification of phenolic compounds from white mulberry, black mulberry, goldenberry and strawberry fruits using HPLC :

Phenolic compounds from white, black mulberry, goldenberry and strawberry fruits were extracted according to the methods of Rodriguez et al. (1994).

\subsubsection{Determination of total flavonoids:}

Total flavonoids content of white, black mulberry, goldenberry and strawberry fruits were determined using the method of Ordonez et al. (2006).

\subsubsection{Determination of vitamins $A, E$ and $C$ :}

Vitamin A content of fruits was determined according to the methods of A.O.A.C. (2010). Vitamin C content was determined by a 2,6- dichloro phenol -indophenol titration method (Zhang, 2004). Vitamin $E$ content was determined with reversed- phase high performance liquid- chromatography (RP- HPLC) method (Zhang, 2004), by employing an HPLC system (Waters-1525, USA) with binary pump, and UV detector $\times 0.05$ AUFS (waters- 2487, USA), with an ultrasphere ODS column $(4.6 \mathrm{~mm} \times 250 \mathrm{~mm}, 5 \mu \mathrm{m}$, Waters, USA), with amobile phase of methanol : water $(98: 2, \mathrm{v} / \mathrm{v})$, detection wave-length: $300 \mathrm{~nm}$, flow rate: $1.7 \mathrm{ml} / \mathrm{min}$, temperature: $25^{\circ} \mathrm{C}$, sample size: $20 \mu \mathrm{l}$. Vitamin $E$ was quantified using authentic $\alpha-, \gamma^{-}$, and $\delta_{-}$tocopherol standards. External standard quantification was performed using a series of five different standard concentrations of $\alpha-, \gamma^{-}$, and $\delta$ tocopherol. B- and $y$ - tocopherols eluted as overlapping peaks, so they were quantified using the $\gamma$ - tocopherol standard curve.

\subsubsection{Determination of $\beta$-Carotene:}

The $\beta$-carotene in the white, black mulberry, goldenberry and strawberry fruits was extracted according to the method described by Koca et al. (2007).

\subsection{6: Determination of the total anthocyanins:}

Total anthocyanin content was determined by the $\mathrm{pH}$ differential method (Giusti and Wrolstad, 1996). Briefly, pH 1.0 buffer was prepared by using $0.2 \mathrm{M} \mathrm{Kcl}$ and $0.2 \mathrm{~N} \mathrm{Hcl}$ solutions. Buffer at $\mathrm{pH} 4.5$ 
was prepared by using sodium acetate and $\mathrm{pH}$ was adjusted with acetic acid. Samples were diluted 25 times with the buffers. Absorbance was measured at 510 and $700 \mathrm{~nm}$ using the microplate reader at $25^{\circ} \mathrm{C}$. The standard used was cyaniding-3-glucoside equivalents (CGE) prepared by using the buffers. Data were expressed as mmol cyaniding-3-glucoside equivalents per gram dry basis (mmol CGE/g DW). Experiments were carried out in five replicates. The absorbance of each sample was calculated using the following equation:

$\mathrm{A}=\left(\mathrm{A}_{510 \mathrm{~nm}} \mathrm{pH} 1.0-\mathrm{A}_{700 \mathrm{~nm}} \mathrm{pH} 1.0\right)-\left(\mathrm{A}_{510 \mathrm{~nm}} \mathrm{pH} 4.5-\mathrm{A}_{700 \mathrm{~nm}} \mathrm{pH} 4.5\right)$.

\subsubsection{Determination of sugers:}

White, black mulberry, goldenberry and strawberry fruits were prepared according to the method described by Melgarejo et al. (2000) with minor modifications. Briefly, the sample of $5 \mathrm{~g}$ fruit was centrifuged at $12000 \mathrm{rpm}$ for $2 \mathrm{~min}$ at $4^{\circ} \mathrm{C}$. Then the supernatant was filtrated with SEP-PAK $\mathrm{C}_{18}$ cartridges and transferred into a vial and used for analysis. Analysis of sugars was performed by HPLC (isocratic program) with $\mu$ bondapak- $\mathrm{NH}_{2}$ column and refractive index (R1) detector using $85 \%$ acetonitrile as a mobile phase. Calculation of concentrations were based on standards prepared in the laboratory.

\subsubsection{Preparation of fruits Juice:}

White, black mulberry, goldenberry and strawberry fruits were blended in a Waring blender (Moulinex Ovatio 3, Ecully Cedex, France) for $5 \mathrm{~min}$. The pulp blends were cooled to room temperature. To remove the seeds and skin residues (fruit pomace), the juice was filtered through cheesecloth. Small aliquots $(25 \mathrm{~mL})$ of each juice (no food preservative was added) were stored at $-20^{\circ} \mathrm{C}$. (El-Sheikh et al. 2010).

\subsubsection{Preparation of Jam:}

White, black mulberry, goldenberry and strawberry jam samples were cooked. The jam formulation was $64.4 \%$ fruit, $35 \%$ sugar, $0.6 \%$ pectin and $45{ }^{\circ}$ Brix. Fruit purée blended with sugar (sucrose) was placed in cooker and stirred and boiled. The cooking temperature did not exceed $80^{\circ} \mathrm{C}$. The mixture was allowed to boil for $20 \mathrm{~min}$, after which soluble solids were measured by a hand type refractometer (7531L). Pectin solution (Grinsted TM Pectin LA 410, Danisco Ingredients, Denmark) was added when the nearly cooked mass achieved a defined solid content of $45^{\circ}$ Brix. When the cooked mass reached $45^{\circ}$ Brix the cooking was finished and the jams were filled into hot glass jars. Afterwards, they were allowed to cool at room 
temperature and stored in the dark at $4{ }^{\circ} \mathrm{C}$ for about one week, until analysis (Scalzo et al. 2005).

\section{2-2-10. Organoleptic evaluation :}

Organoleptic evaluation of the Juice and Jam samples was carried out after cooling. Juice and Jam samples were served to panel of 12 judges. The panelists were asked to evaluate color, odor, taste, appearance and overall acceptability on I to 10 hedonic scales as described by El-Sheikh, (1999).

\subsubsection{Statistical analysis}

The results were presented as means $\pm S$.D. The obtained data were statistically analyzed according to the SPSS-PC (statistical package software, version, 11.0). One way analysis of variance (ANOVA) was used to test the differences between groups (SPSS, 1999).

\section{RESULTS AND DISCUSSION}

\section{3-1-Chemical composition of white mulberry, black mulberry, goldenberry comparing with strawberry fruits $(\mathrm{g} / \mathbf{1 0 0} \mathrm{g}$ as dry weight)}

The results of chemical composition of white mulberry, black mulberry, goldenberry and strawberry are recorded in Table (1). From the tabulated data, the results in Table (1) revealed that white mulberry, black mulberry, goldenberry and strawberry can be considered as good sources of crude protein, ether extract, crude fiber, ash and carbohydrates. Table (1) shows the chemical composition of white mulberry. It contained $79.34 \%$ moisture, $12.98 \%$ protein, $9.03 \%$ ether extract, $6.36 \%$ ash, $8.32 \%$ crude fiber and $63.31 \%$ carbohydrates. These results are in near from those reported by Butt et al. (2008) who found that white mulberry contained $15.31 \%$ crude protein, $(2.09-7.92 \%)$ fat, $(9.9-13.85 \%)$ crude fiber and $(11.3-$ $17.24 \%$ ) ash. The chemical composition of black mulberry is shown in the same Table (1). It could be noticed that moisture content of black mulberry was $76.45 \%$, protein $10.85 \%$, ether extract $7.21 \%$, ash $4.79 \%$, crude fiber $5.45 \%$ and carbohydrates $71.7 \%$. Imran et al. (2007) and Imran et al. (2010) found moisture content of black mulberry was $78.03 \%$, ash $0.87 \%$, lipid $0.60 \%$, protein $1.73 \%$ and fiber $0.81 \%$. 
Table (1): Chemical composition of white mulberry, black mulberry, goldenberry comparing with strawberry (as dry weight)

\begin{tabular}{|l|c|c|c|c|}
\hline $\begin{array}{l}\text { samples } \\
\text { Constituents (\%) }\end{array}$ & White mulberry & Black mulberry & $\begin{array}{l}\text { Goldenberr } \\
y\end{array}$ & Strawberry \\
\hline Moisture & $79.34 \pm 0.55^{\mathrm{b}}$ & $76.45 \pm 0.52^{\mathrm{c}}$ & $77.78 \pm 0.79^{\mathrm{a}}$ & $90.87 \pm 0.84^{\mathrm{a}}$ \\
\hline Protein & $12.98 \pm 0.52^{\mathrm{a}}$ & $10.85 \pm 0.51^{\mathrm{b}}$ & $9.16 \pm 0.59^{\mathrm{ab}}$ & $7.65 \pm 0.74^{\mathrm{c}}$ \\
\hline Ether extract & $9.03 \pm 0.54 \mathrm{~b}^{\mathrm{a}}$ & $7.21 \pm 0.64^{\mathrm{b}}$ & $9.95 \pm 0.52^{\mathrm{a}}$ & $3.74 \pm 0.78^{\mathrm{c}}$ \\
\hline Ash & $6.36 \pm 0.63^{\mathrm{a}}$ & $4.79 \pm 0.79^{\mathrm{ab}}$ & $5.44 \pm 0.62^{\mathrm{ab}}$ & $3.48 \pm 0.66^{\mathrm{b}}$ \\
\hline Crude fiber & $8.32 \pm 0.59^{\mathrm{c}}$ & $5.45 \pm 0.54^{\mathrm{d}}$ & $16.32 \pm 0.57^{\mathrm{a}}$ & $10.32 \pm 0.63^{\mathrm{b}}$ \\
\hline Carbohydrates & $63.31 \pm 0.61^{\mathrm{c}}$ & $71.7 \pm 0.77^{\mathrm{b}}$ & $59.13 \pm 0.61^{\mathrm{d}}$ & $74.81 \pm 0.85^{\mathrm{a}}$ \\
\hline
\end{tabular}

${ }^{*}$ Carbohydrates were calculated by difference (100- (Protein+ Ether extract+ Ash+ Crude fiber).

*Data in the raw followed by diffierent letters are significant at $p<0.05$.

The chemical composition of goldenberry is shown in Table (1). It could be noticed that moisture content of goldenberry was $77.78 \%$, protein $9.16 \%$, ether extract $9.95 \%$, ash $5.44 \%$, crude fiber 16.32 and carbohydrates $59.13 \%$. The obtained results are in disagreement with those reported by Osorio and Roldan (2003) and Repode Calrasco and Zelada (2008). They found that moisture reached $79.8 \%$, protein $1.9 \%$, fat $0.5 \%$, fiber $4.8 \%$ and ash $1.0 \%$. On the other hand, the chemical composition of strawberry is shown in the same Table (1). It could be noticed that moisture content of strawberry was $90.87 \%$, protein $7.65 \%$, ether extract $3.74 \%$, ash $3.48 \%$, crude fiber $10.32 \%$ and carbohydrates $74.81 \%$. The obtained results are in agreement with those reported by Giampieri et al. (2012) who found that moisture content of strawberry was $90.95 \%$. From, these results, white mulberry contained the highest level of protein (12.98\%) and ash $(6.36 \%)$. While, goldenberry is recorded the highest level of ether extract $(9.95 \%)$ and crude fiber (16.32\%) and strawberry contained the highest amount of carbohydrates.

\section{3-2-Phenolic compounds (ppm) of white mulberry, black mulberry, goldenberry comparing with strawberry fruits using (HPLC)}

The phenolic compounds extracted from white mulberry, black mulberry, goldenberry and strawberry were determined using High Performance Liquid Chromatography (HPLC) and the results are listed in Table (2). 
Table (2): Phenolic compounds (ppm) of white mulberry, black mulberry, goldenberry comparing with Strawberry using (HPLC)

\begin{tabular}{|l|c|c|c|c|}
\hline \multicolumn{1}{|c|}{$\begin{array}{l}\text { White } \\
\text { mulberry }\end{array}$} & $\begin{array}{l}\text { Black } \\
\text { mulberry }\end{array}$ & Goldenberry & Strawberry \\
Phenolic compounds & & & & \\
& & & & \\
\hline Gallic acid & 1.42 & 424.96 & 28.66 & 511.24 \\
\hline Pyrogallo & 2.90 & 3.77 & 1.56 & 6.10 \\
\hline Aminobenzoic acid & 0.55 & 2.66 & 1.33 & 9.86 \\
\hline Protocatechuic & 6.97 & 74.05 & 16.66 & 65.32 \\
\hline Catechein & 14.2 & 4.65 & 7.89 & 6.28 \\
\hline Chlorogenic acid & 10.4 & 44.01 & 132.73 & 4.61 \\
\hline Catechol & 0.39 & 7.38 & 1.30 & 20.62 \\
\hline Epi-catchin & 2.13 & 27.34 & 5.19 & 39.71 \\
\hline Caffeine & 1.22 & 17.90 & 1.59 & 31.96 \\
\hline P-OH benzoic acid & 0.39 & 34.57 & 82.69 & 112.04 \\
\hline Caffeic acid & 1.03 & 10.69 & 3.52 & 2.40 \\
\hline Vanillic acid & 7.55 & 45.79 & 8.14 & 19.72 \\
\hline P-coumaric acid & 17.69 & 28.74 & 14.43 & 1.50 \\
\hline Ferulic acid & 18.68 & 56.53 & 1.07 & 3.79 \\
\hline Iso ferulic acid & 0.40 & 2.04 & 1.60 & 18.07 \\
\hline Resveratrol & 2.74 & 0.64 & 0.20 & 1.99 \\
\hline Ellagic acid & 1.35 & 3.50 & 5.46 & $\mathrm{ND}$ \\
\hline Vanillic acid & 0.10 & 74.05 & 24.82 & $\mathrm{ND}$ \\
\hline Alpha coumaric acid & 5.60 & 3.19 & 1.74 & $\mathrm{ND}$ \\
\hline Benzoic acid & 1.77 & 16.98 & 2.47 & $\mathrm{ND}$ \\
\hline 3,4,5 methoxy cinnamic & 1.77 & 0.87 & 1.33 & $\mathrm{ND}$ \\
\hline acid & & & & $\mathrm{N}$ \\
\hline Coumarin & 2.10 & 2.10 & 0.65 & 3.00 \\
\hline Salycilic acid & 18.16 & 6.92 & 351.2 & \\
\hline Cinnamic acid & 119.78 & 894.43 & & \\
\hline $\begin{array}{l}\text { Total phenolic } \\
\text { compounds }\end{array}$ & & & & \\
\hline & & & & \\
\hline
\end{tabular}

*ND: not detected

The data showed that methanolic extract of white, black mulberry and goldenberry contained twenty four phenolic compounds. These compounds included gallic acid, pyrogallo, aminobenzoic acids, protocatechuic, catechein, chlorogenic acid, catechol, epi- catchin, caffeine, $\mathrm{p}$-oH benzoic acid, caffeic acid, vanillic acid, $\mathrm{p}$ - coumaric acid, ferulic acid, iso ferulic acid, resveratrol, ellagic acid, alpha coumaric acid, benzoic acid, 3,4,5 methoxy cinnamic acid, coumarin, salycilic acid and cinnamic acid.

The data in Table (2) showed that methanolic extract in strawberry contained sixteen phenolic compounds. These compounds included gallic acid, pyrogallo, aminobenzoic acids, protocatechuic, catechein, chlorogenic acid, catechol, epi- catchin, caffeine, $\mathrm{p}-\mathrm{oH}$ benzoic acid, caffeic acid, vanillic acid, p- coumaric acid, ferulic acid, iso ferulic acid and resveratrol. These results are in agreement with those reported by Cioroi (2005) who reported that the major phenolic 
compounds in strawberry were gallic acid, protocatechuic acid and p$\mathrm{oH}$ benzoic acid.

From these results in Table (2), it was noticed that, the major phenolic compounds in white mulberry were catechein, chlorogenic acid, vanillic acid, p-coumaric acid, ferulic acid, alpha coumaric acid and salycilic acid. While black mulberry contained high amount of gallic acid, protocatechuic, clorogenic acid, vanillic acid, ferulic acid and vanillic acid. On the other hand, goldenberry had the highest level of chlorogenic acid and $\mathrm{p}-\mathrm{oH}$ benzoic acid and strawberry contained the highest amounts of gallic acid, protocatechuic and $\mathrm{p}-\mathrm{oH}$ benzoic acid. These results are in agreement with those reported by Memon et al. (2010) who reported that the major phenolic compounds in white mulberry were chlorogenic acid, $\mathrm{p}$-oH benzoic acid, gallic acid, vanillic acid, protocatechuic and $\mathrm{p}$ - coumaric acid. On the other hand, the major phenolic compounds in black mulberry were gallic acid, protocatechuic, ferulic acid, vanillic acid, chlorogenic acid, $\mathrm{p}-\mathrm{oH}$ benzoic acid and $p$ - coumaric acid. These results are in agreement with those reported by El-Sheikh et al. (2010) who reported that the major phenolic compounds in goldenberry were ferulic acid, catechin, salicylic, p- coumaric acid and chlorogenic acid.

Phenolic compounds in plants are recognized as important compounds in conferring stability against oxidation. Natural antioxidant phenolics can be classified into a lipophilic group, tocopherols, and a hydrophilic group, including simple phenolics, phenolic acids, anthocyanins, flavonoids and tannins. Eventhough, chemists have elucidated the structures of thousands of phenolics, there are still many compounds that have not yet been fully characterized and they are referred as phenolic extracts. In this ways berry extracts, aromatic plant extracts, essential oils and their components are gaining interest because of their relatively safe and wide acceptance by consumers. Many authors have reported antioxidative and radical-scavenging properties by berries, spices and essential oils. (Hadi et al., 2003); Trombino et al. 2004) and Maestri et al. 2006).

\section{3-3-Flavonoid compounds (ppm) of white mulberry, black mulberry, goldenberry comparing with Strawberry fruits using (HPLC)}

Data in Table (3) showed that, ethanolic extracts had the highest total flavonoids content. The flavonoid compounds extracted from white and black mulberry were determined and the results were listed in Table (3). The data showed that methanolic extract of white and black mulberry contained seventeen flavonoid compounds. These compounds included luteo . 6- arabinose 8-glucose, luteo . 6- glucose 8- arabinose, apig.6- arabinose 8-glactose, apig. 6- rhmnose 8- 
glucose, apig. 6- glucose 8- rhmnose, luteolin, luteo-7- glucose, naringin, rutin, hespiridin, rosmarinic, apig. 7-0-neohespiroside, apig. 7- glucose, quercetrin, quercetin, kaemp. 3- (2-p-coumaroyl), hespirtin, kaempferol, rhmnetin, apignin and acacetin.

These results are in agreement with those reported by Butt et al. (2008) who reported that the major flavonoid compounds in white and black mulberry was rutin, quercetin, kaempferol and quercitrin. From the same Table (3), the data showed that methanolic extract of goldenberry contained eighteen flavonoides compounds. These compounds included luteo . 6- arabinose 8-glucose, luteo . 6- glucose 8- arabinose, apig.6- arabinose 8-glactose, apig. 6- rhmnose 8glucose, apig. 6- glucose 8- rhmnose, luteolin, luteo-7- glucose, naringin, rutin, hespiridin, rosmarinic, apig. 7-0-neohespiroside, apig. 7- glucose, quercetrin, quercetin, kaemp. 3- (2-p-coumaroyl), hespirtin, kaempferol, rhmnetin, apignin and acacetin. These results are in agreement with those reported by El-sheikh et al. (2010) who reported that the major flavonoid compounds in goldenberry were rutin, quercetin, kaempferol and quercitrin.

On the other hand, the data in Table (3) showed that methanolic extract of strawberry contained sixteen flavonoid compounds. These compounds included luteo . 6- arabinose 8-glucose, luteo . 6- glucose 8- arabinose, apig.6- arabinose 8-glactose, apig. 6- rhmnose 8glucose, apig. 6- glucose 8- rhmnose, luteolin, luteo-7- glucose, naringin, rutin, hespiridin, rosmarinic, apig. 7-0-neohespiroside, apig. 7- glucose, quercetrin, quercetin, kaemp. 3- (2-p-coumaroyl), hespirtin, kaempferol, rhmnetin, apignin and acacetin. These results are agreement with those reported by Zheng et al. (2007) who reported that the major flavonoids compounds in strawberry were rutin, quercetin, kaempferol and kaemp. 3- (2-p-coumaroyl).

From these results in Table (3), the major flavonoid compounds in white and black mulberry are rutin, quercetrin, quercetin, kaemp. 3(2-p-coumaroyl) and kaempferol. While, goldenberry recorded higher amounts of rutin, apig. 7- glucose quercetrin, quercetin and kaempferol and strawberry contained higher levels of rutin, quercetin and kaemp. 3- (2-p-coumaroyl).

\section{3-4- Vitamins content of white mulberry, black mulberry, goldenberry comparing with strawberry fruits.}

Vitamins content extracted from white, black mulberry, goldenberry and strawberry were determined by High Performance Liquid Chromatograghy (HPLC) and the results are listed in Table (4). Table (4) shows the vitamins in white mulberry and black mulberry. It contained vitamin A (994.93 and $2077.502 \mathrm{lu} / 100 \mathrm{~g})$, vitamin E (0.197 and $2.677 \mathrm{mg} / \mathrm{g}$ ) and vitamin C (351.14 and $107.46 \mathrm{mg} / \mathrm{g})$, 
respectively. Imran et al. (2010) found that vitamin C in mulberry fruits was in range from 15.20 to $17.03 \mathrm{mg} / 100 \mathrm{~g}$.

Table (3): Flavonoid compounds (ppm) of white mulberry, black mulberry, goldenberry comparing with Strawberry fruits using (HPLC)

\begin{tabular}{|l|c|c|c|c|}
\hline \multicolumn{1}{|c|}{ Fruit samples } & $\begin{array}{l}\text { White } \\
\text { mulberry }\end{array}$ & $\begin{array}{l}\text { Black } \\
\text { mulberry }\end{array}$ & Goldenberry & Strawberry \\
Flavonoid Compounds & & & & \\
\hline $\begin{array}{l}\text { Luteo . 6- arabinose 8- } \\
\text { glucose }\end{array}$ & 0.56 & 0.08 & 0.17 & 0.099 \\
\hline $\begin{array}{l}\text { Luteo . 6- glucose 8- } \\
\text { arabinose }\end{array}$ & 0.21 & 112 & 157 & 3.72 \\
\hline Apig.6- arabinose 8-glactose & 26.2 & 173.1 & 35 & 31 \\
\hline Apig. 6- rhmnose 8-glucose & 0.26 & 174.2 & 118 & 43 \\
\hline Apig. 6- glucose 8- rhmnose & $\mathrm{ND}$ & $\mathrm{ND}$ & 0.072 & $\mathrm{ND}$ \\
\hline Luteolin & $\mathrm{ND}$ & $\mathrm{ND}$ & $\mathrm{ND}$ & 0.29 \\
\hline Luteo- 7- glucose & 40.5 & 174 & 18 & 37 \\
\hline Naringin & $\mathrm{ND}$ & $\mathrm{ND}$ & 0.87 & $\mathrm{ND}$ \\
\hline Rutin & 575.11 & 310 & 792 & 342 \\
\hline Hespiridin & 0.21 & 7.48 & 0.78 & 1.92 \\
\hline Rosmarinic & 0.15 & 0.52 & 0.27 & 0.44 \\
\hline Apig. 7-0-neohespiroside & $\mathrm{ND}$ & 0.40 & $\mathrm{ND}$ & $\mathrm{ND}$ \\
\hline Apig. 7- glucose & 0.08 & 5.58 & 190 & $\mathrm{ND}$ \\
\hline Quercetrin & 327 & 222 & 228 & 0.60 \\
\hline Quercetin & 190 & 310 & 321 & 197 \\
\hline Kaemp. 3- (2-p-coumaroyl) & 185 & 193 & 0.047 & 380 \\
\hline Hespirtin & 0.07 & 0.19 & 0.10 & 0.22 \\
\hline Kaempferol & 373.98 & 540 & 410 & 50 \\
\hline Rhmnetin & 18 & 30 & 30 & 0.025 \\
\hline Apignin & 0.03 & 0.04 & 0.058 & 0.76 \\
\hline Acacetin & 0.12 & 188 & $\mathrm{ND}$ & $\mathrm{ND}$ \\
\hline
\end{tabular}

${ }^{*} \mathrm{ND}$ : not detected

In the same Table (4) goldenberry contained vitamin A $(12335.1 \mathrm{lu} / 100 \mathrm{~g})$, vitamin $\mathrm{E}(0.043 \mathrm{mg} / \mathrm{g})$ and vitamin $\mathrm{C}(236.80$ $\mathrm{mg} / \mathrm{g}$ ). Ramadan (2011) reported that vitamin $\mathrm{C}$ in goldenberry was 43 $\mathrm{mg} / 100 \mathrm{~g}$. On the other hand Puenta et al. (2011) reported that vitamin $E$ in seed oil was $29.70 \mathrm{~g} / \mathrm{kg}$ and $86.30 \mathrm{~g} / \mathrm{kg}$ in pulp and skin oil in goldenberry.

On the other hand, the same Table (4) cleared that strawberry contained vitamin A (2026.40 lu/100g), vitamin E $(0.024 \mathrm{mg} / \mathrm{g})$ and vitamin C (100.493 $\mathrm{mg} / \mathrm{g})$. These results disagreement with those reported by Asami et al. (2003) who reported that vitamin C in strawberry was $32.6 \mathrm{mg} / 100 \mathrm{~g}$.

From these results it can be noticed that goldenberry had the highest vitamin A, black mulberry had the highest in vitamin $E$ and white mulberry had highest in vitamin (C). The variation of vitamins in 
the these fruits depends on many factors, such as degree of maturity at harvest, genetic differences and environmental conditions during fruit development.

Table (4): Vitamins content of white mulberry, black mulberry, goldenberry comparing with Strawberry fruits

\begin{tabular}{|l|c|c|c|}
\hline Fitamins & Vitamin (A) lu/100g & Vitamin (E) $\mathrm{mg} / \mathrm{g}$ & Vitamin (C) $\mathrm{mg} / \mathrm{g}$ \\
& & & \\
\hline White mulberry & & & \\
\hline Black mulberry & 994.93 & 0.197 & 351.14 \\
\hline Goldenberry & 2077.502 & 2.677 & 107.46 \\
\hline Strawberry & 12335.1 & 0.043 & 236.80 \\
\hline
\end{tabular}

IU:- International unit.

\section{3-5-Some reducing and non reducing sugars of white mulberry, black mulberry, goldenberry comparing with strawberry fruits using HPLC}

Some sugars extracted from white mulberry, black mulberry, goldenberry and strawberry were determined using High Performance Liquid Chromatograghy (HPLC) and the results are listed in Table (5).

Data in Table (5) showed some reducing sugars in white mulberry and black mulberry. It could be noticed that fructose was 3.73- $4.05 \mathrm{~g} / 100 \mathrm{~g}$, glucose $3.15-3.39 \mathrm{~g} / 100 \mathrm{~g}$ and total reducing sugars were $7.22-7.95 \mathrm{~g} / 100 \mathrm{~g}$, respectively. These result are in agreement with those reported by Okwu (2005); Khan et al. (2006) and Imran et al. (2010) they found that total reducing sugars in white mulberry and black mulberry were $7.55-8.11 \mathrm{~g} / 100 \mathrm{~g}$, respectively.

In the same Table (5), it could be noticed some reducing and non reducing sugars in goldenberry such as fructose $(1.29 \mathrm{~g} / 100 \mathrm{~g})$, glucose $(1.40 \mathrm{~g} / 100 \mathrm{~g})$, maltose $(0.43 \mathrm{~g} / 100 \mathrm{~g})$, sucrose $(8.05 \mathrm{~g} / 100 \mathrm{~g})$ and total reducing sugars $(4.90 \mathrm{~g} / 100 \mathrm{~g})$. These results are in agreement with those reported by Ramadan and Moersel (2007). On the other hand, the data showed that some reducing and non reducing sugers in strawberry were fructose $(1.72 \mathrm{~g} / 100 \mathrm{~g})$, glucose $(1.31$ $\mathrm{g} / 100 \mathrm{~g})$, sucrose $(0.07 \mathrm{~g} / 100 \mathrm{~g})$ and total reducing sugars (3.97 $\mathrm{g} / 100 \mathrm{~g}$ ). These results are agreement with those reported by Giampieri et al. (2012) who found that total reducing sugars in strawberry were $4.89 \mathrm{~g} / 100 \mathrm{~g}$. From these results, it can be noticed that black mulberry contain the highest levels of fructose, glucose and total reducing sugar, while goldenberry was the highest in non reducing suger such as sucrose. 
Table (5): Some reducing and non reducing sugars of white mulberry, black mulberry, goldenberry comparing with Strawberry using HPLC

\begin{tabular}{|l|c|c|c|c|c|}
\hline \multirow{2}{*}{ Fruit samples } & \multicolumn{3}{|c|}{ Reducing sugars $(\mathrm{g} / 100 \mathrm{~g})$} & $\begin{array}{r}\text { Non reducing } \\
\text { sugar }(\mathrm{g} / 100 \mathrm{~g})\end{array}$ & $\begin{array}{r}\text { Total Reducing } \\
\text { sugars } \\
(\mathrm{g} / 100 \mathrm{~g})\end{array}$ \\
\cline { 2 - 5 } & Fructose & Glucose & Maltose & Sucrose & 7.22 \\
\hline White mulberry & 3.73 & 3.15 & ND $^{*}$ & ND & 7.95 \\
\hline Black mulberry & 4.05 & 3.39 & ND & ND & 4.90 \\
\hline Goldenberry & 1.29 & 1.40 & 0.43 & 8.05 & 3.97 \\
\hline Strawberry & 1.72 & 1.31 & ND & 0.07 & \\
\hline
\end{tabular}

*ND:not detected

\section{3-6- Anthocyanin and beta carotene of white mulberry, black mulberry, goldenberry and strawberry fruits.}

Data in Table (6) showed that anthocyanin of white, black mulberry, goldenberry comparing with strawberry. From these results, it can be noticed that black mulberry contained the highest amount of anthocyanin (58.83 mg/100g), followed by strawberry (43.22 $\mathrm{mg} / 100 \mathrm{~g}$ ). These results are in agreement with those reported by Ozgen et al. (2009) who reported that black mulberry was rich in anthocyanin. On the other hand, Zheng et al. (2007) found that the strawberry was rich in anthocyanin $(23.68 \mathrm{mg} / 100 \mathrm{~g})$.

Table (6): Anthocyanin and beta carotene of white mulberry, black mulberry, goldenberry and strawberry

\begin{tabular}{|l|l|l|}
\hline Fruit samples & $\begin{array}{l}\text { Anthocyanin } \\
(\mathrm{mg} / 100 \mathrm{gm})\end{array}$ & $\begin{array}{l}\text { Beta carotenoids } \\
(\mathrm{mg} / 100 \mathrm{gm})\end{array}$ \\
\hline White mulberry & 0.36 & 13.7 \\
\hline Black mulberry & 58.83 & 14.0 \\
\hline Goldenberry & 0.39 & 1450 \\
\hline Strawberry & 43.22 & 13.9 \\
\hline
\end{tabular}

Beta carotenoids extracted from white mulberry, black mulberry, goldenberry and strawberry were determined by High Performance Liquid Chromatography (HPLC) and the results are listed in Table (6). From these results, it can be noticed that, goldenberry contained the highest amount of beta carotenoids (1450 mg/100mg) comparing with other fruits. These results are in agreement with those reported by ElSheikh et al. (2008), El-Sheikh et al. (2010) and Demiray et al. (2013) who reported that the goldenberry was very rich in B- caroteine (722 mg/100g).

3-7- Organoleptic properties of strawberry juice containing different ratios of white, black mulberry and goldenberry fruits

Data in Table (7) show the organoleptic properties of strawberry juices containing different ratios of white, black mulberry and goldenberry (25, 50 and $75 \%)$. 
From these results, it could be noted that juice samples containing (25\% white mulberry+ $75 \%$ strawberry) had the highest score for all tested sensory. This sample was better than the control and other levels in white mulberry. In case of black mulberry, the results in Table (7) showed that the juice samples containing $(75 \%$ black mulberry+ $25 \%$ strawberry) recorded the highest scores for all tested sensory characteristics comparing with that containing other levels and it was also better than the control sample. The results in the same table revealed that the juice samples contained $(75 \%$ goldenberry+ $25 \%$ strawberry) had the highest scores for all tested sensory characteristics comparing with those containing other levels. It couid be noted that sample possess sensory characteristics better than those of the control.

From these results, it could be also noted that juice samples containing $25 \%$ white mulberry+ $75 \%$ strawberry, $75 \%$ black mulberry+ $25 \%$ strawberry and $75 \%$ goldenberry+ $25 \%$ strawberry had the highest scores for all tested sensory characteristics. These three samples were better than the control and the other levels as shown in Table (7). These results may be due to the variation of chemical composition of juice samples comparing with the white, black mulberry, goldenberry and strawberry in Table (1).

Table (7): Organoleptic properties of strawberry juice containing different ratios of white, black mulberry and goldenberry

\begin{tabular}{|c|c|c|c|c|c|}
\hline Type of juice & $\begin{array}{c}\text { Appearance } \\
(10)\end{array}$ & $\begin{array}{c}\text { Color } \\
(10)\end{array}$ & $\begin{array}{l}\text { Odor } \\
(10)\end{array}$ & $\begin{array}{c}\text { Taste } \\
(10)\end{array}$ & $\begin{array}{c}\text { Overall } \\
\text { acceptability } \\
(10)\end{array}$ \\
\hline $100 \%$ Strawberry juice & $8 \pm 0.58^{b}$ & $8 \pm 0.58^{\mathrm{cd}}$ & $8 \pm 0.58^{\mathrm{ef}}$ & $8 \pm 0.58^{\mathrm{cd}}$ & $8 \pm 0.56^{\mathrm{cd}}$ \\
\hline $25 \%$ white mulberry $+75 \%$ strawberry juice & $9 \pm 0.00^{\mathrm{DC}}$ & $8.67 \pm 0.33^{\mathrm{d}}$ & $8.67 \pm 0.33^{19}$ & $8.67 \pm 0.33^{\mathrm{d}}$ & $9 \pm 0.00^{\mathrm{cd}}$ \\
\hline $50 \%$ white mulberry $+50 \%$ strawberry juice & $6.33 \pm 0.33^{\mathrm{a}}$ & $6.67 \pm 0.33^{\mathrm{abc}}$ & $5.33 \pm 0.33^{\mathrm{a}}$ & $5 \pm 0.58 \pm^{a}$ & $5.33 \pm 1.20^{\mathrm{a}}$ \\
\hline $75 \%$ white mulberry $+25 \%$ strawberry juice & $6.33 \pm 0.88^{\mathrm{a}}$ & $6.67 \pm 0.67^{\mathrm{abc}}$ & $7 \pm 0.58^{\text {cde }}$ & $5.67 \pm 0.33^{\text {ab }}$ & $6 \pm 0.00^{\mathrm{ab}}$ \\
\hline $25 \%$ black mulberry $+75 \%$ strawberry juice & $5.67 \pm 0.67^{a}$ & $6 \pm 0.58^{\text {ab }}$ & $5.67 \pm 0.33^{\text {ab }}$ & $6.33 \pm 0.33^{\text {ab }}$ & $7.33 \pm 0.33^{\mathrm{DC}}$ \\
\hline $50 \%$ black mulberry $+50 \%$ strawberry juice & $6 \pm 0.00^{\mathrm{a}}$ & $7 \pm 0.58^{\mathrm{DC}}$ & $6.67 \pm 0.33^{\mathrm{bcd}}$ & $7 \pm 0.58^{\mathrm{DC}}$ & $7.33 \pm 0.67^{\mathrm{DC}}$ \\
\hline $75 \%$ black mulberry $+25 \%$ strawberry juice & $9.5 \pm 0.29^{c}$ & $9 \pm 0.00^{\mathrm{d}}$ & $8 \pm 0.00^{\mathrm{et}}$ & $9.33 \pm 0.067^{\mathrm{d}}$ & $9.67 \pm 0.33^{d}$ \\
\hline $25 \%$ goldenberry $+75 \%$ strawberry juice & $5.67 \pm 0.33^{\mathrm{a}}$ & $5.33 \pm 0.33^{\mathrm{a}}$ & $6 \pm 0.58^{\mathrm{abc}}$ & $6 \pm 0.00^{\text {ab }}$ & $7.33 \pm 0.33^{\mathrm{DC}}$ \\
\hline $50 \%$ goldenberry $+75 \%$ strawberry juice & $6.33 \pm 0.33^{a}$ & $6.67 \pm 0.33^{\mathrm{abc}}$ & $7.33 \pm 0.33^{\mathrm{de}}$ & $7 \pm 0.58^{\mathrm{DC}}$ & $7.67 \pm 0.33^{\mathrm{DC}}$ \\
\hline $75 \%$ goldenberry $+25 \%$ strawberry juice & $9 \pm 0.00^{\mathrm{bc}}$ & $9 \pm 0.58^{d}$ & $9.33 \pm 0.33^{9}$ & $8.67 \pm 0.33^{\mathrm{d}}$ & $9.67 \pm 0.33^{d}$ \\
\hline
\end{tabular}

Values followed by the same letter in column are not significantly different at $p \leq 0.05$.

Sharoba and Ramadan (2011) who reported that cape gooseberry is a promising tropical fruit. Recently, processing of tropical fruits started in many countries. This trend has caused an upswing in the fruit industries in the fruit- growing countries, which endeavor to promote and improve production, to be competitive for both domestic demand and export markets. Rheology science has many applications in food acceptability, food processing and food handling. Studies on rheological behavior of juice and its concentrates could be important for applications related to handling, storage, processing, quality control, pumping, heat and mass transfer operations and sensory 
analysis of food. Suh et al. (2003), Ercisli and orhan (2007) and Fazaeli et al. (2013) reported that black mulberry is popular edible fruit, which originates from Iran. Black mulberry juice is proven to be a very concentrated source of polyphenols and anthocyanins. Many studies showed that red color juices such as those of pomegranates, grapes, and different berries have beneficial effects on human health due to their high anthocyanin content and antioxidant activity.

\section{3-8- Organoleptic properties of strawberry jam containing different ratios of white, black mulberry and goldenberry fruits}

Results in Table (8) show the organoleptic properties of strawberry jams containing different ratio of white, black mulberry and goldenberry (25, 50 and $75 \%)$. Results indicated values as means of the scores given by 10 panelists based on a 10 point scale. Results in table showed that (50\% white mulberry+ $50 \%$ strawberry) jam had relatively the best for all tested sensory. This sample was better than the control and the other levels in white mulberry. In case of black mulberry, the results in Table (7) showed that the jam samples containing ( $75 \%$ black mulberry+ $25 \%$ strawberry) recorded the highest scores for all tested sensory characteristics comparing with that containing the other levels and it was also better than the control sample. The results in the same table revealed that the jam samples contained ( $25 \%$ goldenberry+ $75 \%$ strawberry) had the highest scores for all tested sensory characteristics comparing with that containing other levels. It couid be noted that this sample possess sensory characteristics better than those of the control.

From the data presented in Table (8), the panelists were able to distinguish differences in the quality characteristics, and sensory scores were significantly different for all treatments compared to the control jam. From these results, it could be also noted that jam samples containing $(50 \%$ white mulberry $+50 \%$ strawberry, $75 \%$ black mulberry $+25 \%$ strawberry and $25 \%$ goldenberry $+75 \%$ strawberry) had the highest scores for all tested sensory characteristics. These three samples were better than the control and other levels as shown in Table (8). These results may be due to the variation of chemical composition of jam samples comparing with the white, black mulberry, goldenberry and strawberry in Table (1).

(Da Silva Pinto et al. (2008), Da Silva Pinto et al. (2007) and Cordenunsi et al. (2002) reported that strawberry represents one of the most important sources of bioactive compounds with antioxidant activity, together with other berries. Their results had shown that the processing procedure had greater impact on decreasing of bioactive compounds than storage time. Although some losses could have 
occurred, the results suggested that jams may still represent important sources of bioactive compounds in the diet.

Table (8): Organoleptic properties of strawberry jam containing different ratios of white, black mulberry and goldenberry

\begin{tabular}{|c|c|c|c|c|c|}
\hline Type of jam & $\begin{array}{l}\text { Appearance } \\
(10)\end{array}$ & $\begin{array}{l}\text { Color } \\
\text { (10) }\end{array}$ & $\begin{array}{l}\text { Odor } \\
\text { (10) }\end{array}$ & $\begin{array}{l}\text { Taste } \\
\text { (10) }\end{array}$ & $\begin{array}{l}\text { Overall acceptability } \\
\text { (10) }\end{array}$ \\
\hline $100 \%$ strawberry jam & $9 \pm 0.00^{a e}$ & $9 \pm 0.00^{\circ}$ & $8 \pm 0.33^{000}$ & $8.67 \pm 0.33^{\mathrm{oc}}$ & $9 \pm 0.58^{\text {ocd }}$ \\
\hline $25 \%$ white mulberry $+75 \%$ strawberry jam & $6.33 \pm 0.89^{\mathrm{ab}}$ & $7.33 \pm 0.67^{\mathrm{bc}}$ & $7.67 \pm 0.88^{\mathrm{abc}}$ & $7.67 \pm 0.33^{\mathrm{ab}}$ & $7.33 \pm 0.33^{\mathrm{ab}}$ \\
\hline $50 \%$ white mulberry $+50 \%$ strawberry jam & $9.33 \pm 0.33^{\mathrm{e}}$ & $9.33 \pm 0.33^{\mathrm{d}}$ & $9.33 \pm 0.33^{\mathrm{cd}}$ & $9.33 \pm 0.33^{c}$ & $9.67 \pm 0.33^{\mathrm{d}}$ \\
\hline $75 \%$ white mulberry $+25 \%$ strawberry jam & $5.67 \pm 0.33^{\mathrm{a}}$ & $6 \pm 0.00^{\mathrm{a}}$ & $7 \pm 0.00^{200}$ & $7.33 \pm 0.33^{\text {ab }}$ & $8 \pm 0.00^{\text {abcod }}$ \\
\hline $25 \%$ black mulberry $+75 \%$ strawberry jam & $7.33 \pm 0.67^{\mathrm{bc}}$ & $6.67 \pm 0.33^{\mathrm{ab}}$ & $6.67 \pm 0.67^{\mathrm{a}}$ & $7.33 \pm 0.67^{\mathrm{ab}}$ & $7.67 \pm 0.33^{\text {abc }}$ \\
\hline $50 \%$ black mulberry $+50 \%$ strawberry jam & $7 \pm 0.00^{\mathrm{bc}}$ & $8.33 \pm 0.33^{\text {cd }}$ & $7.67 \pm 0.88^{\mathrm{abc}}$ & $6.67 \pm 0.88^{\mathrm{a}}$ & $6.67 \pm 1.33^{\mathrm{a}}$ \\
\hline $75 \%$ black mulberry $+25 \%$ strawberry jam & $9 \pm 0.00^{\mathrm{de}}$ & $9.33 \pm 0.33^{\mathrm{d}}$ & $10 \pm 0.00^{\mathrm{d}}$ & $9.67 \pm 0.33^{c}$ & $9.33 \pm 0.33^{\mathrm{cd}}$ \\
\hline $25 \%$ goldenberry $+75 \%$ strawberry jam & $9 \pm 0.00^{\text {वe }}$ & $9 \pm 0.00^{\circ}$ & $9.33 \pm 0.33^{\infty 0}$ & $9.33 \pm 0.33^{c}$ & $9.67 \pm 0.33^{\circ}$ \\
\hline $50 \%$ goldenberry $+75 \%$ strawberry jam & $8 \pm 0.00^{c 0}$ & $7 \pm 0.58^{\mathrm{aj}}$ & $7 \pm 0.58^{\mathrm{ajo}}$ & $8.67 \pm 0.33^{\text {oc }}$ & $8 \pm 0.00^{\text {abed }}$ \\
\hline $75 \%$ goldenberry $+25 \%$ strawberry jam & $7 \pm 0.00^{\mathrm{bc}}$ & $7 \pm 0.58^{\text {ab }}$ & $7.33 \pm 0.33^{\mathrm{ab}}$ & $7 \pm 0.58^{\mathrm{a}}$ & $7.33 \pm 0.67^{\mathrm{ab}}$ \\
\hline
\end{tabular}

Values followed by the same letter in column are not significantly different at $p \leq 0.05$.

\section{REFERENCES}

A.O. A. C. (2010). Association official analytical chemists. Official methods of analysis $17^{\text {th }}$ ed., Washington, DC., U. S. A.

Asami, D. K.; Hong, Y.; Barrett, D. M. and Mitchell, A. E. (2003). Comparison of the total phenolic and ascorbic acid content of freeze- dried and air- dried marionberry, strawberry and corn grown using conventional, organic and sustainable agriculture practices. J. Agric. Food Chem. 51, 1237-1241.

Bulletin Of The Agricultural Statistics. (2015). Arab Republic of Egypt, ministry of agriculture and land reclamation, economic affairs sector. Part (2) Summer and nili crops 2013/2014.

Butt, M. S.; Nazir, A.; Sultan, M. T. and Schroen, K. (2008). Morus alba L. nature's functional tonic. Critical Reviews in Food Science and Nutrition, 19:505-512.

Celik, H., Ozgen, M., Serce, S. and Kaya, C. (2008). Phytochemical accumulation and antioxidant capacity at four maturity stages of cranberry fruit. Sci. Hortic. 117, 345-348.

Cioroi, M (2005). The identification of phenolic acids by HPLC method from strawberries. Agroalimentary Processes and Tech, (1), 211216.

Cordenunsi B.R.; Nascimento J.R.O.; Genovese M.I. and Lajolo F.M. (2002). Influence of cultivar on quality parameters and chemical composition of strawberry fruits grown in Brazil. Journal of Agricultural and Food Chemistry 50: 2581-2586.

Da Silva Pinto M., Maria Lajolo F., and Genovese M.I. (2007). Bioactive compounds and antioxidant capacity of strawberry jams. Plant Foods Hum Nutr. 62:127-131.

Da Silva Pinto M.; Maria Lajolo F. and Genovese M.I. (2008). Bioactive compounds and quantification of total ellagic acid in strawberries (Fragaria $x$ ananassa Duch.) Food Chemistry 107: 1629-1635.

Demiray, E.; Tulek, Y. and Yilmaz, Y. (2013). Degradation kinetics of lycopene, $\beta$-carotene and ascorbic acid in tomatoes during hot air drying. LWT-Food Science and Technology 50:172-176. 
Du, Q.; Zheng, J., and Xu, Y. (2008). Composition of anthocyanins in mulberry and their antioxidant activity. Journal of Food Composition and Analysis, 21, 390-395.

El-Sheikh, D.M. (1999). Production and Evaluation of Some Low Caloric Jams. Ph. D. Thesis, Food Technology Dept., Fac. of Agric., Cairo Univ.

El-Sheikh, A. F.; Zaki, M. S.; Bakr, A. A.; El Habashy, M. M. and Montet, D. (2008). Pysico-chemical properties and biochemical composition of Physalis (Physalis pubescens L.) fruits. Global Science Books Ltd., UK, Food, 2, 124-130.

El-Sheikh, A. F.; Zaki, M. S.; Bakr, A. A.; El Habashy, M. M. and Montet, D. (2010). Biochemical and sensory quality of Physalis (Physalis pubescens $L$ ) juice. Journal of Food Processing and Preservation, 34(3):541-555.

Ercisli, S., and Orhan, E. (2007). Chemical composition of white (Morus alba), red (Morus rubra) and black (Morus nigra) mulberry fruits. Food Chem 103(4): 1380-1384.

Fazaeli, M.; Emam-Djomeh, Z.; Omid, M. and Kalbasi-Ashtari, A. (2013). Prediction of the physicochemical properties of spray-dried black mulberry (Morus nigra) juice using artificial neural networks. Food Bioprocess Technol 6:585-590.

Giampieri, F.; Tulipani, S.; Alvarez-Surarez, J.M.; Quiles, J.L.; Mezzetti, B. and Battino, M. (2012). The strawberry: composition, nutritional quality, and impact on human health. Nutrition. 28(1): 9-19.

Giusti, M. M. and Wrolstad, R. E. (1996). Characterization of red radish anthocyanins. Journal of food Sciences, 61(2), 322-326.

Häkkinen, S.H.; Kärenlampi, S.O.; Heinonen, I.M.; Mykkänen, H.M. and Riitta, A.T. (1999). Content of the flavonols quercetin, myricetin, and kaempferol in 25 edible berries. J. Agric. Food Chem. 47 , 2274-2279.

Häkkinen S.H., and Törrönen A.R. (2000) Content of flavonols and selected phenolic acids in strawberries and vaccinium species: influence of cultivar, cultivation site and technique. Food Research International 33: 517-524.

Hadi, S.M.; Asad, S.F.; Singh, S.; Ahmad, A. and Khan, N.U. (2003). A putative mechanism for anticancer and apoptosis inducing properties of plant derived polyphenolic antioxidants. In Recent Progress in Medicinal Plants vol. 8 (Majumdar DK, Govil JN and Singh VK eds.). Studium Press. 83.

Imran, M.; Khan, H.; Shah, M.; Khan, R. and Khan, F. (2010). Chemical composition and antioxidant activity of certain Morus species. $J$ Zhejiang Univ Sci B11 12:973-980.

Imran, M.; Talpur, F. N.; Jan, M. S.; Khan, A. and Khan, I. (2007). Analysis of nutritional components of some wild edible plants. J. Chem. Soc. Pak., 29(5):500-508.

Koca, N.; Burdurlu, H.S. and Karadeniz, F. (2007). Kinetics of colour changes in dehydrated carrots. Journal of Food Engineering 78:449-455. 
Khan, T.; Ahmad, M.; Khan, R.; Khan, H.; Ejaz, A., and Choudhary, M. I. (2006). Evaluation of phytomedicinal potentials of selected plants of Pakistan. Am. Lab., 38(9):20-22.

Lee, J. Y.; Moon, S. O.; Kwon, Y.J.; Rhee, S.J.; Park, H.R. and Choi, S. W. (2004). Identification and quantification of anthocyanins and flavonoids in mulberry (Morus sp.) cultivars. Food Sci. Biotechnol. 13, 176-184.

Maestri D.M.; Nepote V.; Lamarque A. L. and Zygadlo J.A. (2006). Natural products as antioxidants. Research Signpost 37/661 (2), Fort P.O., Trivandrum-695 023, Kerala, India.

Mayorga, H.; Knapp, H.; Winterhalter, P. and Duque, C. (2001). Glycosidically bound flavor compounds of cape gooseberry (Physalis peruviana L.).Journal of Agriculturaland Food Chemistry, 49(4), 1904-1908.

McCain, R. (1993). Goldenberry, passionfruit and white sapote: potential fruits for cool subtropical areas, in New Crops, ed. by Janick $\mathbf{J}$ and Simon JE, Wiley, New York, pp. 479-486.

Memon, A. A.; Memon, N.; Luthria, D. L.; Bhanger, M. I. and Pitafi, A. A. (2010). Phenolic acids profiling and antioxidant potential of mulberry (Morus Lavigata W., Morus nigra L., Morus alba L.) leaves and fruits grown in Pakistan. Pol. J. Food Nutr. Sci. 60(1): 25-32.

Melgarejo, P., Salazar, D.M., and Artes, F. (2000). Organic acids and sugars composition of harvested pomegranate fruits. Eur. Food Res. Technol. 211, 185-190.

Meyers K. J., Watkins C. B., Pritts M. P., and Liu R. H. (2003). Antioxidant and antiproliferative activities of strawberries. Journal of Agricultural and Food Chemistry 51: 6887-6892.

Morton, J.F. (1987). Cape gooseberry, in fruits of warm climates, ed. by Morton JF. Creative Resource Systems, Winterville, NC, pp. 430434.

Naderi, G.A.; Asgary, S.; Sarraf-Zadegan, N.; Oroojy, H. and Afshin-Nia, F. (2004). Antioxidant activity of three extracts of Morus nigra. Phytother. Res. 18, 365-369.

Okwu, D. E. (2005). Phytochemicals, vitamins and mineral contents of two Nigerian medicinal plants. Int. J. Mol. Med. Adv. Sci., 1(4):375381.

Ordonez, J. D.; Gomez, M. A. and Vattuone, M. I. (2006). Antioxidant activities of Sechium edule (Jacq.) Swartz extracts. Food Chem., 97: 452-458.

Osorio, D. and Roldan, J. (2003). Volvamos al campo: manual de la uchuva. Bogotá: Grupo Latino LTDA.

Ozgen M.; Serce S. and Kaya C. (2009). Phytochemical and antioxidant properties of anthocyanin rich Morus nigra and Morus rubra fruits. Scientia Hort. 119, 275-279.

Perez-Gregorio, M. R.; Regueiro, J.; Alonso- Gonzalez, E.; PastranaCastro, L. M. and Simal-Gandara, J. (2011). Influence of alcoholic fermentation process on antioxidant activity and phenolic levels 
from mulberrries (Morus nigra L.). LWT- Food Science and Technology. 44, 1793-1801.

Prior, R.L. (2003). Absorption and metabolism of anthocyanins: Potential health effect. In: Phytochemicals: Mechanisms of Action. CRC Press Inc., Boca Raton, FL.

Puente, L.A.; Pinto-Munoz, C.A.; Castro, E.S. and Cortes, M. (2011). Physalis peruviana Linnaeus, the multiple properties of a highly functional fruit: A review. Food Research International 44:17331740.

Ramadan, M.F. (2011). Bioactive phytochemicals, nutritional value, and functional properties of cape gooseberry (Physalis peruviana): An overview. Food Res. Int.44, 1830-1836.

Ramadan, M. F. and Moersel, J. T. (2004). Goldenberry: A novel fruit source of fat soluble bioactives. Inform 15,130-131.

Ramadan, M. F. and Moersel, J. T. (2007). Impact of enzymatic treatment on chemical composition, physicochemical properties and radical scavenging activity of goldenberry (Physalis peruviana L.) juice. Journal of the Science of Food and Agriculture, 87(3),452-460.

Rodriguez, S. D.; Hadley, M. and Holm, E. T. (1994). Phenolic in aqueous potato peel extract: extraction identification and degradation. J. Food Sci, 59(2):649-651.

Repode Carrasco, R., and Zelada, C. (2008). Determinación de la capacidad antioxidante y compuestos bioactivos de frutas nativas peruanas. Revista de la Sociedad Química Perú, 74(2), 108-124.

Scalzo, J.; Politi, A.; Pellegrini, N.; Mezzetti, B. and Battino, M. (2005). Plant genotype affects total antioxidant capacity and phenolic contents in fruit. Nutrition, 21(2),207-213.

Sharoba, A. M. and Ramadan, M. F. (2011). Rheological behavior and physicochemical characteristics of golden berry (Physalis peruviana) juice as affected by enzymatic treatment. J. of Food Processing and Preservation 35:201-219.

SPSS, (1999).SPSS-PC for the IBM PC/XT computer. Version 11.0. SPSS Inc., II. U.S.A.

Stintzing, F.C.; Carle, R.; Frei, B. and Wrolstad, R.E. (2002). Color and antioxidant properties of cyanidin-based anthocyanin pigments. J. Agric. Food Chem. 50, 6172-6180.

Suh, H. J.; Noh, D. O.; Kang, C. S.; Kim, J. M. and Lee, S. W.(2003). Thermal kinetics of color degradation of mulberry fruit extract. Nahrung- Food, 47(2), 132-135.

Trombino, S.; Serini, S.; Di Nicuolo, F.; Celleno, L.; Andò, S.; Picci, N.; Calviello, G. and Palozza P. (2004). Natural products as antioxidants J. Agric. Food Chem., 52, 2411.

Wang, S. Y. and Jiao, H. (2000) Scavenging capacity of berry crops on superoxide radicals, hydrogen peroxide, hydroxyl radicals, and singlet oxygen. Journal of Agricultural and Food Chemistry 48: 5677-5684. 
Wang, S. Y.; Zheng, W. and Galletta, G. J. (2002) Cultural system affects fruit quality and antioxidant capacity in strawberries. Journal of Agricultural and Food Chemistry 50: 6534-6542.

Zafra-Stone, S.; Yasmin, T.; Bagchi, M.; Chatterjee, A.; Vinson, J.A. and Bagchi, D. (2007). Berry anthocyanins as novel antioxidants in human health and disease prevention. Mol. Nutr. Food Res. 51, 675-683.

Zhang, S.H. (2004). Food Analysis, China Light. Ind. Press, Beijing. Pp. 144-210.

Zheng, Y.; Wang, S. Y.; Wang, C. Y. and Zheng, W. (2007). Changes in strawberry phenolics, anthocyanins, and antioxidant capacity in response to high oxygen treatments. Egypt J. Agric. Res., (40) 4957.

التعرف على المركبات الحيوية الفعالة فى ثمار التوث المصرى واستخدامها فى تحسين جودة بعض الأغذية التماتية

*مصطفى أحمد عون **أحمد محمد جعفر *سعدالله محمد صالح **مروه مصطفى شاهين

* قسم تكنولوجيا الأغذيةـ كلية الزراعة- جامعة كفر الشيخ. ** معهد بحوث تكنولوجيا الأغذيةـ. مركز البحوث الزراعية- الجيزة - مصرة

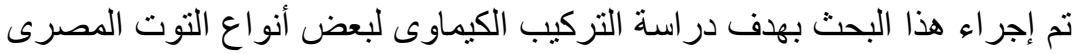

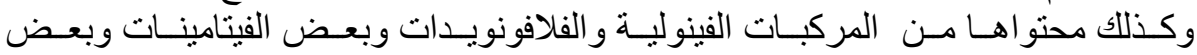

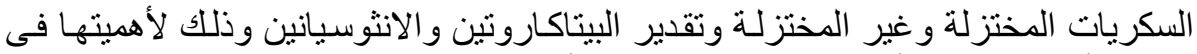

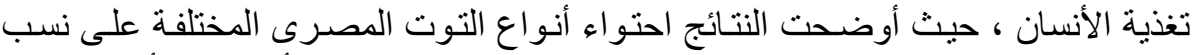

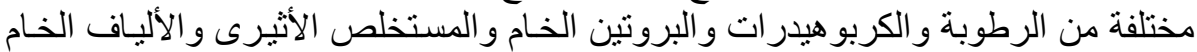

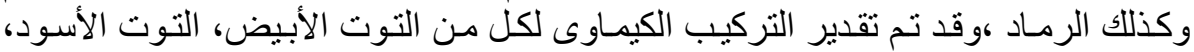

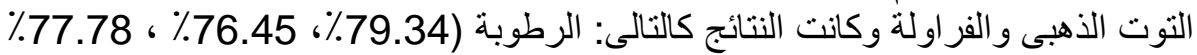

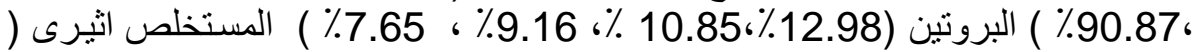

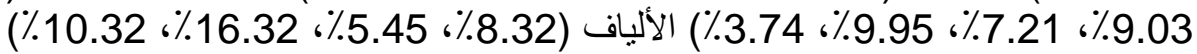

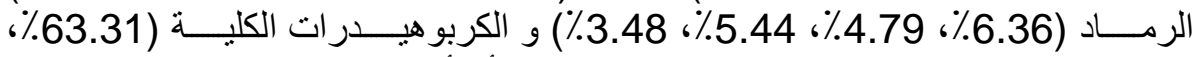

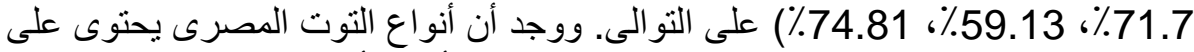

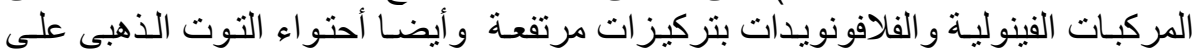

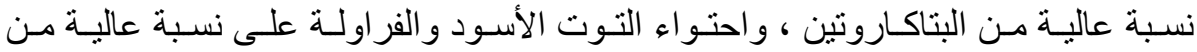

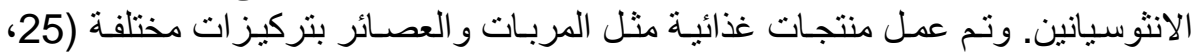

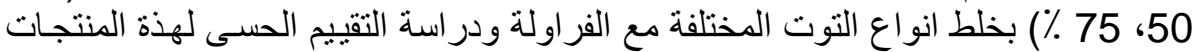
و لرفع القيمة التغذوية أخان 